\title{
Review
}

\section{Blue revolution in India: Status and future perspectives}

\author{
W. S. LAKRA AND A. GOPALAKRISHNAN* \\ NABARD Chair Unit, Mumbai Research Centre of ICAR-Central Marine Fisheries Research Institute, Versova \\ Mumbai - 400 061, Maharashtra, India \\ ${ }^{2}$ ICAR-Central Marine Fisheries Research Institute, Ernakulam North P. O., Kochi- 682 018, Kerala, India \\ e-mail:wslakra@gmail.com
}

\begin{abstract}
Fisheries and aquaculture development in India witnessed impressive growth in recent years. The country is rich in aquatic genetic resources distributed from deep sea to the cold Himalayan rivers sharing about $10 \%$ of the global aquatic biodiversity. The capture fisheries production in the country has more or less stabilised but the growth in inland aquaculture has been tremendous during the past three decades. Freshwater aquaculture contributes to about 85-90\% of the farmed fish. In 2018-19, India was the second largest producer of fish in the world with a total production of 13.4 million $t$ comprising 3.7 million $t$ from marine and 9.7 million $t$ from inland sector. The technological advances enabled the country to significantly enhance production and productivity particularly in the fresh and brackishwater aquaculture sectors. Recent progress in cage culture in reservoirs and mariculture in the sea offer new avenues for aquaculture diversification and development. Major constraints in capture fisheries production are depleted stocks due to habitat degradation, overexploitation, poor governance, climate change, in addition to harvest and post-harvest losses. The key problems in culture fisheries include low average productivity due to low adoption of technology, disease prevalence, non-availability of quality seed and cost effective feed for desired species. Cutting edge translational research and technology upscaling and dissemination along with improved governance, fisher and farmer centric fisheries policy support and large scale capacity building in both aquaculture and marine fisheries sectors are the key strategies for achieving the targets of blue revolution in the country. This comprehensive review of the Indian fisheries and aquaculture provides latest information on resources, sectoral production, technology intervention and policy formulations along with recommendations as well as future perspectives.
\end{abstract}

Keywords: Aquaculture, Blue revolution, Current status, Indian fisheries, Perspectives, Policies

\section{Introduction}

Fisheries and aquaculture are playing a pivotal role in food production, nutritional security and employment generation for millions of people. The sector is contributing significantly to Indian economy and foreign exchange earnings. The rich aquatic genetic resources of the country ranging from deep seas to the Himalayan lakes and rivers support about $10 \%$ of the global biodiversity in terms of fish and shellfish species whose number has currently reached 3137 with an additional 462 exotic species (Lal and Jena, 2019). The fisheries sector has grown from a traditional livelihood activity in the fifties and sixties to science and technology led commercial enterprise in the past four decades (Ayyappan, 2012; Ayyappan et al., 2013). Today, India ranks second in global fish production registering an annual growth rate of over 7\% with a production of 13.4 million $\mathrm{t}$ in 2018-19 which includes 3.7 million $\mathrm{t}$ and 9.7 million $\mathrm{t}$ from marine and inland sector respectively (Fig. 1). The sector contributes $6.58 \%$ to the gross domestic product (GDP) of the agriculture sector and $1.03 \%$ to the total GDP of the country. Fish and fishery products exports have emerged as the largest group in agriculture exports and in value terms, accounted for USD 6.73 billion in 2018-19. The fisheries potential of the country has been estimated at 22.31 million $t$ with 5.31 and 17 million $t$ from marine and inland sector respectively (GoI, 2020b). Andhra Pradesh is the frontrunner in aquaculture production in the country with a boom in fish culture, first observed with Indian major carps (IMCs) and then Pangasius, resulting in expansion of pond area to 142,000 ha and subsequent massive increases in inland farmed fish production to 1.5 million t (Belton et al., 2017). The technological advances and environmental changes have made it necessary to seriously address the issues of sustainability. In fact, the global fisheries and aquaculture development destined to feed the billions are all confronted with sustainability issues (Christopher et al., 2015; Taryn et al., 2020).

\section{Fisheries resources}

India with a coastline of $8118 \mathrm{~km}$ and the exclusive economic zone (EEZ) of 2.02 million $\mathrm{km}^{2}$ ( 0.86 million $\mathrm{km}^{2}$ on the west coast, 0.56 million $\mathrm{km}^{2}$ on the east coast and $0.60 \mathrm{~km}^{2}$ around the Andaman and Nicobar Islands) 


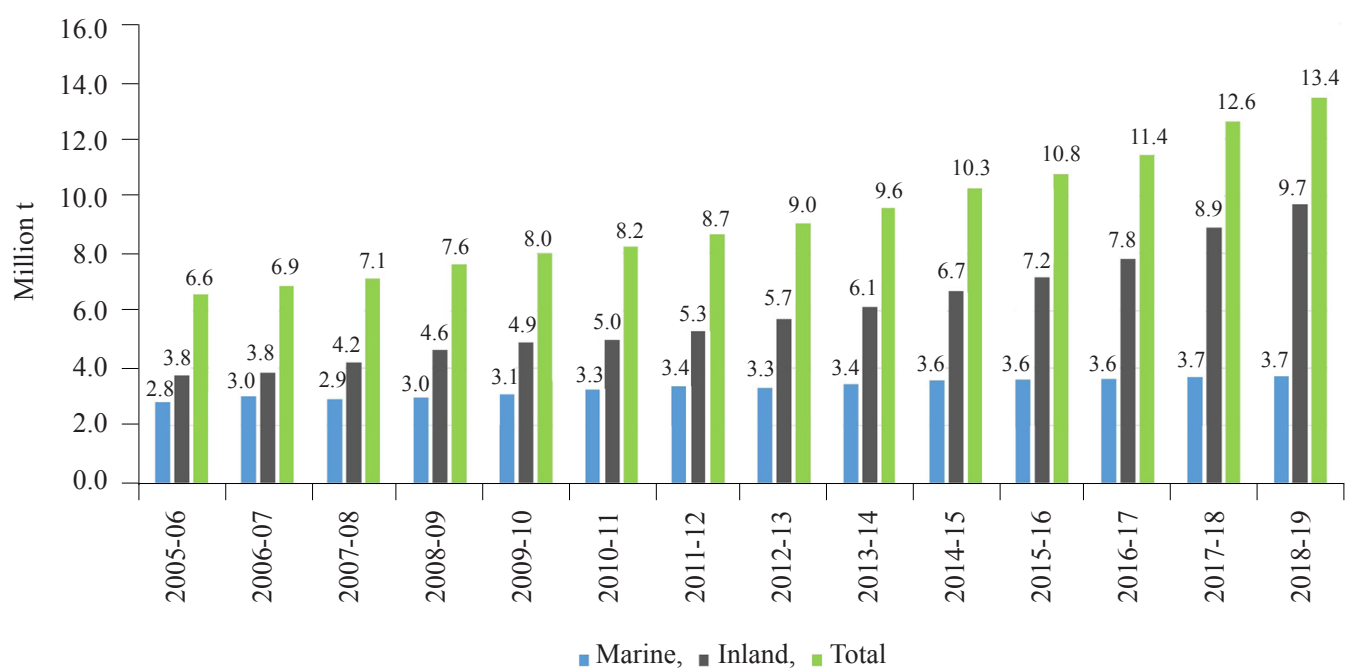

Fig. 1. Fish production in India from 2005-06 to 2018-19 (Source: Ministry of Fisheries, Animal Husbandry and Dairying, Govt. of India)

provides huge potential for marine capture and culture fisheries. The inland fishery resources broadly include 0.38 million $\mathrm{km}$ stretch of rivers and canals, 2.70 million ha of reservoirs, 2.47 million ha of ponds and tanks, 0.43 million ha of beels, 0.34 million ha derelict water bodies/oxbow lakes and 0.96 million ha brackishwater area. The diverse cold water resources are distributed in the upland streams, rivers, lakes and reservoirs located at medium to high altitudes, in the Himalayan and North-eastern region

\section{Capture fisheries}

The annual exploitation from the marine sector was 3.56 million $t$ in 2019 against the potential of 5 million $t$ (CMFRI, 2020). Marine capture fisheries play a vital role in India's economy, providing employment and income to over two million people. The total number of marine fishing fleet is estimated to be 280491 consisting of traditional crafts (181284), motorised traditional crafts (44578) and mechanised boats (53684) and the share of traditional, motorised and mechanised sector in the catch is estimated at 9, 26 and 65\% respectively (Shinoj et al., 2020). India's marine fish harvest mostly centres around coastal waters up to $100 \mathrm{~m}$ depth and about $90 \%$ of the catch comes from within $50 \mathrm{~m}$ resulting in overexploitation of species in the nearshore waters. Coastal resources up to $100 \mathrm{~m}$ depth are subjected to intense fishing pressure and is expected at levels close to or exceeding optimum sustainable limit. While the inshore waters have been almost exploited to the maximum sustainable yield (MSY) levels, the contribution from the deep sea has been insignificant, hitherto directed at shrimps only. The country is presently harvesting about $12 \%$ of the potential and the balance can be optimally harvested using a judicious mix of technology, infrastructure and human resources development. Hence, after having almost reached a plateau in production from the coastal waters, the scope for increasing fish production from marine sources now lies in the exploitation of the deep sea. In order to harvest deep sea resources, diversification of the existing deep sea fishing fleet and introduction of resource specific vessels for long lining, purse seining and squid jigging are favourable options attracting more attention.

Inland open water resources in the form of rivers, estuaries, floodplain wetlands, reservoirs, backwaters and lagoons are invaluable aquatic resources of the country offering tremendous scope for capture and culture fisheries development. India is blessed with vast area of inland open water in terms of rivers and canals, reservoirs, ponds and tanks, flood plains, beels and wetlands and the inland saline and brackishwater resources. The vast and varied cold water fishery resources extend from northeastern to north-western Himalayan ranges and parts of Western Ghats in peninsular regions encompassing about ten states. These cold water resources are spread as upland rivers, streams, high and low altitude natural lakes and reservoirs. The coldwater fisheries resources include 258 indigenous, exotic, cultivable and non-cultivable fish species belonging to 21 families and 76 genera (Debajit Sarma et al., 2011).

The role of various State Governments in the development of fisheries and aquaculture is of paramount importance with regard to governance, management, technology transfer to the stakeholders 
and the implementation of various provincial and central regulations as well as schemes, with fisheries being a State subject. The share of various states in the total fish production is presented in Table 1 (GoI, 2018). The share of Inland fisheries in 1950-51 to the total fish production of the country was $29 \%$ which increased to $72 \%$ in $2018-19$ (Fig. 2). Gujarat leads the marine fish landings followed by Andhra Pradesh, Tamil Nadu, Maharashtra, Karnataka and Kerala (Fig. 3). Andhra Pradesh is the largest fish producer in the inland sector followed by West Bengal and together they contribute more than $40 \%$ of the total inland fish production in the country (Fig. 4).
The fisheries research and development in India is managed by one of the largest institutional frame work under the central government and its linkages with the state governments (Fig. 5). The sector has attracted more attention in recent years, with new initiatives and focus on innovation, technology development as well as upscaling and profitability of farmers. The scientific advancements through the sustained research and technology development by Indian Council of Agricultural Research (ICAR), many other central departments, State Agricultural Universities and several other R\&D organisations are leading the growth. In order to provide

Table 1. State/UT-wise inland and marine fish production during 2014-15 to 2017-18 (million t) (Source: GoI, 2018)

\begin{tabular}{|c|c|c|c|c|c|c|c|c|c|c|c|c|}
\hline \multirow{2}{*}{ States/UTs } & \multicolumn{3}{|c|}{$2014-15$} & \multicolumn{3}{|c|}{$2015-16$} & \multicolumn{3}{|c|}{$2016-17$} & \multicolumn{3}{|c|}{$2017-18$} \\
\hline & Inland & Marine & Total & Inland & Marine & Total & Inland & Marine & Total & Inland & Marine & Total \\
\hline Andhra Pradesh & 1.503 & 0.475 & 1.979 & 1.832 & 0.520 & 2.352 & 2.186 & 0.580 & 2.766 & 2.845 & 0.605 & 3.450 \\
\hline Arunachal Pradesh & 0.004 & 0.00 & 0.004 & 0.004 & 0.00 & 0.004 & 0.004 & 0.00 & 0.004 & 0.004 & 0.00 & 0.004 \\
\hline Assam & 0.283 & 0.00 & 0.283 & 0.294 & 0.00 & 0.294 & 0.307 & 0.00 & 0.307 & 0.327 & 0.00 & 0.327 \\
\hline Bihar & 0.480 & 0.00 & 0.480 & 0.507 & 0.00 & 0.507 & 0.509 & 0.00 & 0.509 & 0.588 & 0.00 & 0.588 \\
\hline Chhattisgarh & 0.314 & 0.00 & 0.314 & 0.342 & 0.00 & 0.342 & 0.377 & 0.00 & 0.377 & 0.457 & 0.00 & 0.457 \\
\hline Goa & 0.003 & 0.115 & 0.118 & 0.005 & 0.107 & 0.112 & 0.004 & 0.114 & 0.118 & 0.006 & 0.118 & 0.124 \\
\hline Gujarat & 0.111 & 0.698 & 0.810 & 0.112 & 0.697 & 0.810 & 0.117 & 0.699 & 0.816 & 0.134 & 0.701 & 0.835 \\
\hline Haryana & 0.111 & 0.00 & 0.111 & 0.121 & 0.00 & 0.121 & 0.144 & 0.00 & 0.144 & 0.190 & 0.00 & 0.190 \\
\hline Himachal Pradesh & 0.011 & 0.00 & 0.011 & 0.012 & 0.00 & 0.012 & 0.013 & 0.00 & 0.013 & 0.013 & 0.00 & 0.013 \\
\hline Jammu and Kashmir & 0.020 & 0.00 & 0.020 & 0.020 & 0.00 & 0.020 & 0.020 & 0.00 & 0.020 & 0.021 & 0.00 & 0.021 \\
\hline Jharkhand & 0.106 & 0.00 & 0.106 & 0.116 & 0.00 & 0.116 & 0.145 & 0.00 & 0.145 & 0.190 & 0.00 & 0.190 \\
\hline Karnataka & 0.223 & 0.400 & 0.623 & 0.169 & 0.412 & 0.581 & 0.159 & 0.399 & 0.557 & 0.188 & 0.414 & 0.603 \\
\hline Kerala & 0.202 & 0.524 & 0.726 & 0.211 & 0.517 & 0.728 & 0.161 & 0.431 & 0.593 & 0.148 & 0.414 & 0.563 \\
\hline Madhya Pradesh & 0.109 & 0.00 & 0.109 & 0.115 & 0.00 & 0.115 & 0.139 & 0.00 & 0.139 & 0.143 & 0.00 & 0.143 \\
\hline Maharashtra & 0.144 & 0.464 & 0.608 & 0.146 & 0.434 & 0.580 & 0.200 & 0.463 & 0.663 & 0.131 & 0.475 & 0.606 \\
\hline Manipur & 0.031 & 0.00 & 0.031 & 0.032 & 0.00 & 0.032 & 0.032 & 0.00 & 0.032 & 0.033 & 0.00 & 0.033 \\
\hline Meghalaya & 0.006 & 0.00 & 0.006 & 0.011 & 0.00 & 0.011 & 0.012 & 0.00 & 0.012 & 0.012 & 0.00 & 0.012 \\
\hline Mizoram & 0.006 & 0.00 & 0.006 & 0.007 & 0.00 & 0.007 & 0.008 & 0.00 & 0.008 & 0.008 & 0.00 & 0.008 \\
\hline Nagaland & 0.008 & 0.00 & 0.008 & 0.008 & 0.00 & 0.008 & 0.009 & 0.00 & 0.009 & 0.009 & 0.00 & 0.009 \\
\hline Odisha & 0.336 & 0.133 & 0.470 & 0.377 & 0.145 & 0.521 & 0.455 & 0.153 & 0.608 & 0.534 & 0.151 & 0.685 \\
\hline Punjab & 0.115 & 0.00 & 0.115 & 0.120 & 0.00 & 0.120 & 0.133 & 0.00 & 0.133 & 0.137 & 0.00 & 0.137 \\
\hline Rajasthan & 0.045 & 0.00 & 0.045 & 0.042 & 0.00 & 0.042 & 0.050 & 0.00 & 0.050 & 0.054 & 0.00 & 0.054 \\
\hline Sikkim & 0.00 & 0.00 & 0.00 & 0.00 & 0.00 & 0.00 & 0.00 & 0.00 & 0.00 & 0.00 & 0.00 & 0.00 \\
\hline Tamil Nadu & 0.240 & 0.457 & 0.698 & 0.243 & 0.467 & 0.709 & 0.197 & 0.472 & 0.669 & 0.185 & 0.497 & 0.682 \\
\hline Telangana & 0.268 & 0.00 & 0.268 & 0.237 & 0.00 & 0.237 & 0.199 & 0.00 & 0.199 & 0.270 & 0.00 & 0.270 \\
\hline Tripura & 0.065 & 0.00 & 0.065 & 0.069 & 0.00 & 0.069 & 0.072 & 0.00 & 0.072 & 0.077 & 0.00 & 0.077 \\
\hline Uttarakhand & 0.004 & 0.00 & 0.004 & 0.004 & 0.00 & 0.004 & 0.004 & 0.00 & 0.004 & 0.005 & 0.00 & 0.005 \\
\hline Uttar Pradesh & 0.494 & 0.00 & 0.494 & 0.505 & 0.00 & 0.505 & 0.618 & 0.00 & 0.618 & 0.629 & 0.00 & 0.629 \\
\hline West Bengal & 1.438 & 0.179 & 1.617 & 1.493 & 0.178 & 1.671 & 1.525 & 0.177 & 1.702 & 1.557 & 0.185 & 1.742 \\
\hline Andaman and Nicobar Islands & 0.00 & 0.037 & 0.037 & 0.00 & 0.037 & 0.037 & 0.00 & 0.039 & 0.039 & 0.00 & 0.039 & 0.040 \\
\hline Chandigarh & 0.00 & 0.00 & 0.00 & 0.00 & 0.00 & 0.00 & 0.00 & 0.00 & 0.00 & 0.00 & 0.00 & 0.00 \\
\hline Dadra and Nagar Haveli & 0.00 & 0.00 & 0.00 & 0.00 & 0.00 & 0.00 & 0.00 & 0.00 & 0.00 & 0.00 & 0.00 & 0.00 \\
\hline Daman and Diu & 0.00 & 0.032 & 0.032 & 0.00 & 0.023 & 0.023 & 0.001 & 0.023 & 0.024 & 0.001 & 0.024 & 0.025 \\
\hline Delhi & 0.001 & 0.00 & 0.001 & 0.001 & 0.00 & 0.001 & 0.001 & 0.00 & 0.001 & 0.001 & 0.00 & 0.001 \\
\hline Lakshadweep & 0.00 & 0.013 & 0.013 & 0.00 & 0.016 & 0.016 & 0.00 & 0.030 & 0.030 & 0.00 & 0.021 & 0.021 \\
\hline Puducherry & 0.006 & 0.042 & 0.047 & 0.007 & 0.047 & 0.054 & 0.004 & 0.046 & 0.050 & 0.007 & 0.042 & 0.050 \\
\hline India & 6.691 & 3.569 & 10.260 & 7.162 & 3.600 & 10.762 & 7.806 & 3.625 & 11.431 & 8.902 & 3.688 & 12.59 \\
\hline
\end{tabular}


1950-51

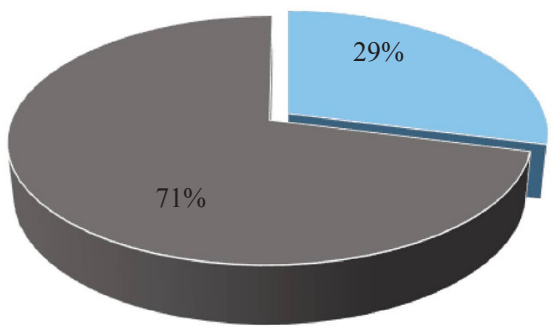

2018-19

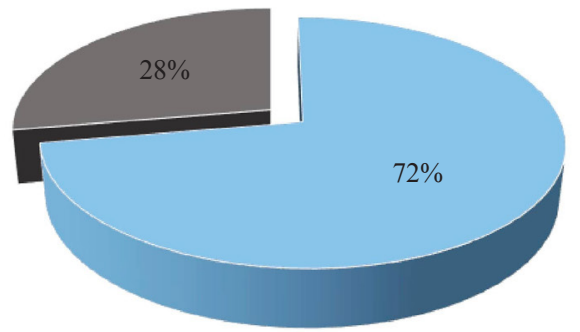

Marine

Fig. 2. Percentage contribution of inland and marine fisheries during 1950-51 and 2018-2019. (Source: Ministry of Fisheries, Animal Husbandry and Dairying, Govt. of India)

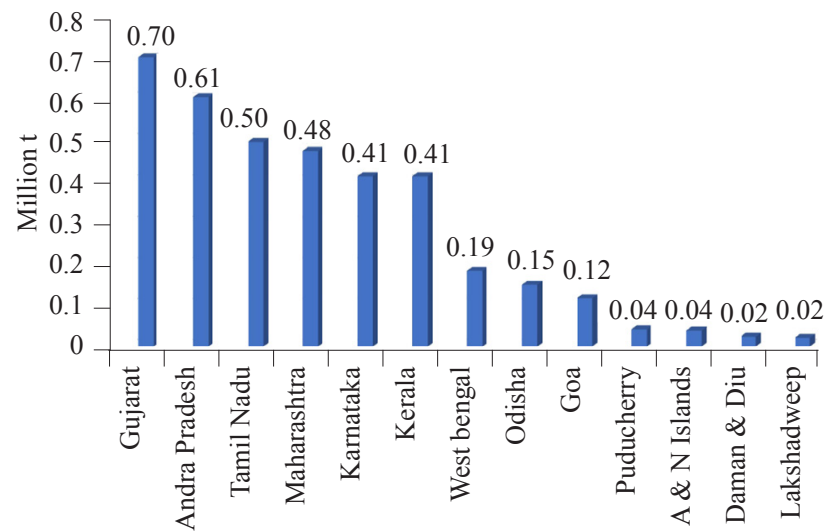

States/UTs

Fig. 3. Major inland fish producing states during 2018-19 (Source: Ministry of Fisheries, Animal Husbandry and Dairying, Govt. of India)

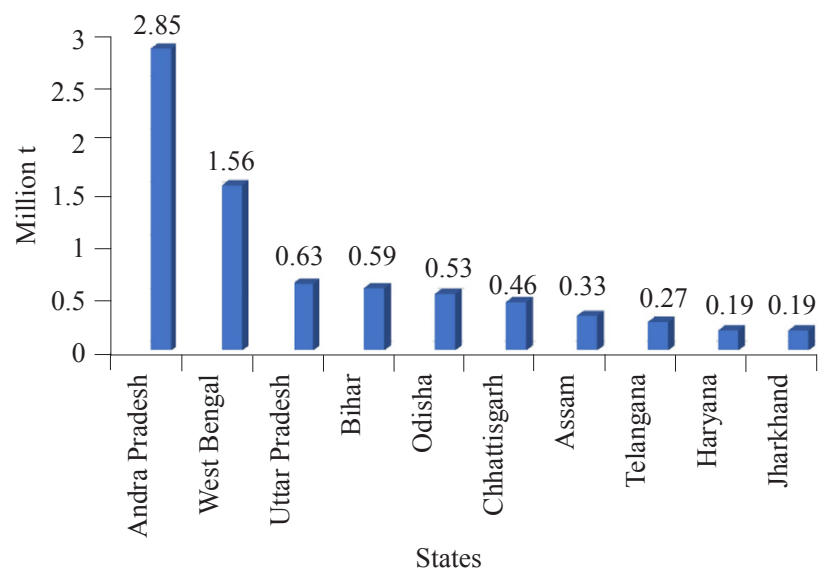

Fig. 4. Major marine fish producing states during 2018-19 (Source: Ministry of Fisheries, Animal Husbandry and Dairying, Govt. of India)

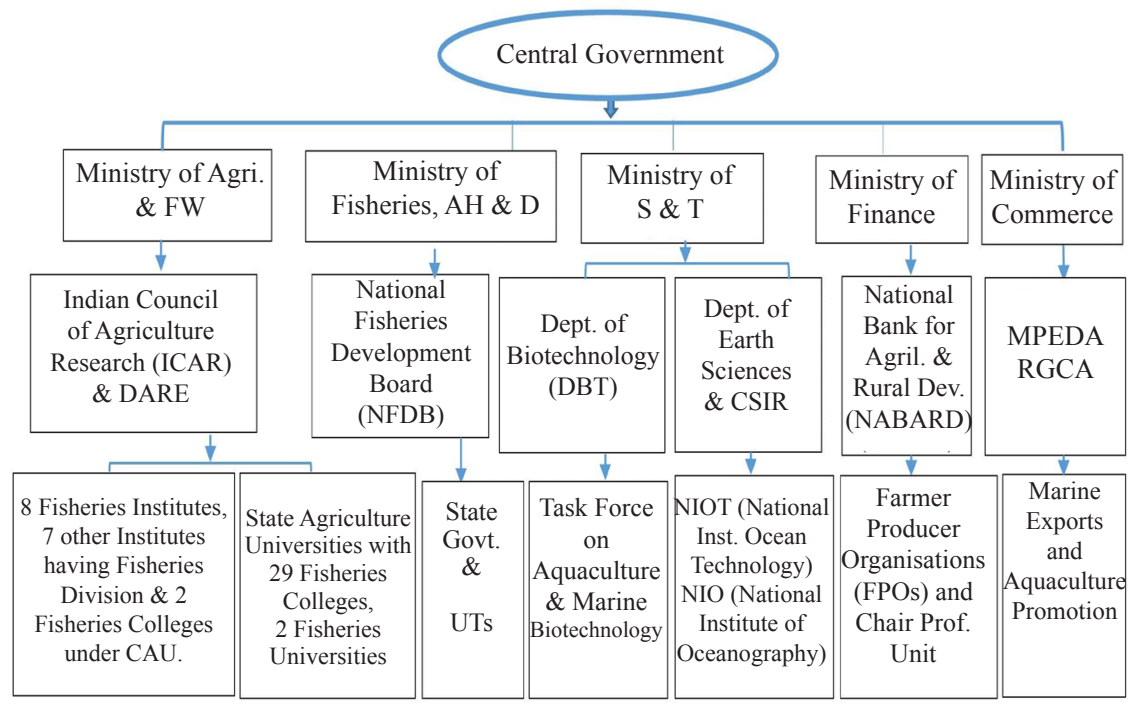

Fig. 5. Institutional strength and frame work of the fisheries sector 
a boost to the sector and bring about a revolution owing to its potential, the Govt. of India launched a centrally sponsored scheme named "Blue revolution: Integrated development and management of fisheries" in 2015. The scheme is being implemented through the National Fisheries Development Board (NFDB). The second new initiative is the creation of a separate Department of Fisheries (DoF) under the new Ministry of Fisheries, Animal Husbandry and Dairying (MFAH\&D). A mega scheme for the sector named Pradhan Mantri Matasya Sampada Yojna (PMMSY) was announced during 2019-20. It is aimed to bring economic revolution through blue revolution which includes sustainable and responsible development of the fisheries sector with the highest ever investment worth ₹20,050 crores (more than 200 billion USD) during 2020-2025 (Box 1).

\section{Aquaculture}

Aquaculture is one of the fastest growing food production sectors globally. The seafood (fish and other aquatic foods cultivated both in freshwater and marine environment) production is growing at a rate of $8 \%$ per year and accounts for almost half of all seafood destined for human consumption (Edwards et al., 2019). India is the second largest producer of fish and offers a vast potential for aquaculture which is growing at an annual growth rate of over $7 \%$, contributing significantly to the economy and nutrition of millions of people. Indian aquaculture encompasses a range of species and cultivation systems which is spread across the freshwater and marine ecosystems exhibiting spectacular growth (Katiha et al., 2005; Munilkumar and Nandeesha, 2007; Nair, 2014; Jayasankar, 2018).

\section{Freshwater aquaculture}

It is estimated that freshwater aquaculture contributes to over $95 \%$ of the total production. The three Indian major carps (IMCs) namely Catla [Labeo $(=$ Catla) catla], rohu (Labeo rohita) and mrigal (Cirrhinus mrigal) are the key species contributing to about $80-90 \%$ of the freshwater aquaculture production. The other species which contributes to about $10-20 \%$ of the production

\section{BOX 1. Blue Revolution Scheme}

A. The Department of Fisheries (DoF), Ministry of Fisheries, Animal Husbandry and Dairying (MFAH\&D) has embarked on an umbrella scheme for Blue Revolution from 2015 to 2020 by restructuring all existing schemes of Govt. of India at a total outlay of ₹3000 crores (USD 30 billion) with the following components:

- National Fisheries Development Board (NFDB) and its activities

- Development of inland fisheries and aquaculture

- Development of marine fisheries, infrastructure and post-harvest operations

- Strengthening of Database and Geographical Information System of the fisheries sector

- Institutional arrangement for fisheries sector

- Monitoring, Control and Surveillance (MCS) and other need-based Interventions

- National Scheme of Welfare of Fishermen

B. Pradhan Mantri Matsya Sampada Yojna (PMMSY)

The MFAH\&D, Government of India has announced a new scheme named Pradhan Mantri Matsya Sampada Yojna (PMMSY) from 2020-2025 with an investment of ₹20050 crores (more than USD 200 billion) and with the following objectives:

- Harnessing of fisheries potential in a sustainable, responsible, inclusive and equitable manner.

- Enhancing fish production and productivity through expansion, intensification, diversification and productive utilisation of land and water.

- Modernising and strengthening of value chain, post-harvest management and quality improvement

- Doubling fishers' and fish farmers' income and generation of employment

- Enhancing contribution to Agriculture GVA (Gross Value Added) and exports

- Social, physical and economic security for fishers and fish farmers

- Robust fisheries management and regulatory framework 
include minor carps, catfish, silver carp, grass carp and common carp. After the historic breakthrough in induced breeding of IMCs in 1957, the major expansion of Indian aquaculture happened in the 1970s; wherein the technology of composite fish farming of three Indian and three exotic carps was developed and disseminated to the farmers leading to a paradigm shift in carp farming, greatly enhancing the production and productivity (Sinha et al., 1973). Subsequently, with the adoption of polyculture, semi-intensive and intensive carp culture practices, a production ranging from 5-15 $\mathrm{t} \mathrm{ha}^{-1}$ has been demonstrated. The recent years have witnessed successful culture technology development towards diversification of species including new candidates such as minor carps [Labeo calbasu, L. fimbriatus, L. gonius, L. bata, Sytomus (=Puntius) sarana and Amblypharyngodon mola], catfishes [Clarias magur, Heteropneustes fossilis, Pangasius pangasius, Wallago attu, Sperata (=Mystus) seenghala, S. aor and Ompok pabda]; murrels (Channa striata, C. marulius); Anabas testudineus and tilapia (Oreochromis mossambicus, O. niloticus). The freshwater prawn farming once a boon in Andhra Pradesh, West Bengal and Kerala has been on the decline since 2006 due to inbreeding depression, disease problems and reduced growth. The genetic improvement programme initiated at ICAR-Central Institute of Freshwater Aquaculture (ICAR-CIFA), Bhubaneswar in collaboration with World Fish, Malaysia is expected to solve the problems of reduced growth and improve the disease resistance in Macrobrachium rosenbergii. The freshwater prawn farming has huge potential in India for food and nutritional security (New et al., 2010). Commercial farming of the exotic catfish, Pangasianodon hypophthalmus, under mono culture systems with production levels of 15-50 $\mathrm{t} \mathrm{ha}^{-1}$ year $^{-1}$ have become popular among the entrepreneurs especially in the states of Andhra Pradesh, West Bengal and Chatishgarh. In recent years, trout culture is also being undertaken in the hill states of Jammu and Kashmir, Ladakh, Himachal Pradesh and Sikkim. The states of Andhra Pradesh, West Bengal, Bihar, Assam, Panjab, Haryana, Chhattisgarh and Jharkhand have shown impressive growth in freshwater aquaculture in recent years (Jayasankar, 2018).

\section{Brackishwater aquaculture}

The brackishwater fish farming traditionally practiced in the Bheries of West Bengal and Pokali paddy fields of Kerala has transformed into a commercial aquaculture enterprise from 1980 onwards. In fact, shrimp farming emerged as the fastest-growing food producing sector in 1990s contributing substantially to the Indian economy and exports. The brackishwater aquaculture production in India touched 0.75 million $t$ valued at USD7 billion during
2017-18 and the key cultivable shrimp species included Peneaus monodon and $P$. vannamei. The fish species namely Chanos chanos, Lates calcarifer, Mugil cephalus, Etroplus suratensis and Trachinotus blochii have emerged as new candidates for diversification. It is reported that out of 3.9 million ha of the brackishwater area comprising estuaries, coastal lagoons, lakes, backwaters, tidal creeks, canals, mudflats and mangroves, only $11 \%$ is currently utilised for brackishwater aquaculture (NFDB, 2019). In addition, about 9 million ha of salt affected inland saline soils in the states of Haryana, Punjab, Rajasthan, Uttar Pradesh and Gujarat offers immense scope for inland saline water aquaculture (NFDB, 2019). A recent breakthrough in the successful commercial farming of the white legged shrimp ( $P$. vannamei) in the inland saline waters of Haryana and Punjab has demonstrated the potential of converting waste into wealth (Lakra et al., 2014). The brackishwater aquaculture sector is expected to contribute significantly in the future because of its vast potential. Major deterrent in brackishwater aquaculture, particularly in shrimp farming, is the availability of specific pathogen free (SPF) seed and disease management during the culture period. Shrimp production in the country touched 0.7 million $t$ in $2017-18$, valued over ₹3000 crores (USD 30 billion). Presently, about $90 \%$ of the brackishwater aquaculture production is of the exotic white shrimp, $P$. vannamei. Considering the disease and production cost issues in $P$. vannamei farming, the Indian white shrimp, $P$. indicus is being intensely researched for domestication as an alternative indigenous species to the shrimp farmers (Vijayan, 2019).

\section{Mariculture and cage farming}

Global fish consumption is predicted to increase over $20 \%$ by 2025 as both human population and economic development would rise in coming decades (FAO, 2020). Culture of fish in cages and pens offers great scope for enhanced production, meeting the rising demand for seafood. Globally, fish provides about 3.2 billion people with $20 \%$ of their animal protein intake as per capita consumption has increased from $9 \mathrm{~kg}$ in 1961 to $20.5 \mathrm{~kg}$ in 2018 (FAO, 2020).

Mariculture research and development in India was systematically initiated during 1980s by ICAR-Central Marine Fisheries Research Institute (ICAR-CMFRI), Kochi. The National Institute of Ocean Technology (NIOT) and Marine Products Export Development Authority (MPEDA) have also contributed in the development of this sector. The technological advances include captive maturation, seed production and developing technologies for farming of various finfishes (cobia, pompano, seabass, groupers, snappers, breams and ornamental fishes); shellfishes (mussels, oysters, clams, lobsters, 
shrimps and crabs) and seaweeds (Syda Rao et al., 2014; Ranjan et al., 2018; Kaladharan et al., 2019). However, the marine aquaculture is still in its infancy and commercial farming is yet to take off despite its huge potential to enhance seafood production in the country. The projected mariculture potential of the country based on the resources available in the maritime states and union territories and islands is $8-16$ million $\mathrm{t}$, while the current mariculture production is around $0.05 \mathrm{t}$. Hence, there is an urgent need for technology upscaling, establishment of hatcheries in various states for seed production of candidate species. Identification of suitable sites all along the Indian coast with financial, technological capacity building and policy support to the stakeholders for adopting mariculture activities as a commercial enterprise as well as an alternate livelihood activity involving traditional fishermen is strongly advocated. It is reported that more than $30 \%$ of India's EEZ lies around the islands where immense opportunities exist for mariculture of fish and shellfish (NFDB, 2020a).

\section{Ornamental fisheries}

The global aquarium fish trade including accessories is estimated at USD 25 billion. India contributes less than $1 \%$ by quantity and $12 \%$ by value in spite of its rich diversity of ornamental fish including about 200 freshwater and 400 marine species. The North-eastern region and Western Ghats are the two hot spots for freshwater ornamental fish species. The marine ornamentals are widely distributed along the coral reef habitats of Andaman and Nicobar and Lakshadweep
Islands; Gulf of Mannar and Gulf of Kutch. The Indian ornamental fish trade currently involves largely the freshwater species which are mostly exotic and culture based (Felix et al., 2013). On the contrary, the marine ornamentals are mostly captured from wild and only $2 \%$ are culture based. Hence, the potential for development of ornamental fisheries of indigenous species is immense and the Central Government has identified this sector as one of the thrust areas for augmenting exports and meeting the increasing domestic demand. It is a ₹300 crores (USD 3 billion) domestic industry which is poised for phenomenal growth with a potential of over ₹1000 crores (USD 10 billion) and it is estimated that roughly about 10 million people are engaged in aquarium trade in the country. Considering the huge potential, a mega research and development project on ornamental fisheries was launched by ICAR, in 2018 involving 7 fisheries institutes with an objective to develop and upscale breeding technologies of high value key indigenous fish species including both freshwater and marine along with development of cost effective feeds and capacity building of entrepreneurs.

\section{Harvest, post-harvest processing and seafood trade}

India is a leading country in seafood export (Fig. 6). It is reported that almost $70 \%$ of the fish caught is marketed fresh and the remaining is used for processing, drying, smoking and fish meal production. The key markets for India include USA, South-east Asia, European Union (EU), Japan and Middle East. The major exports are in frozen and chilled form with only $10 \%$ or so in the value added

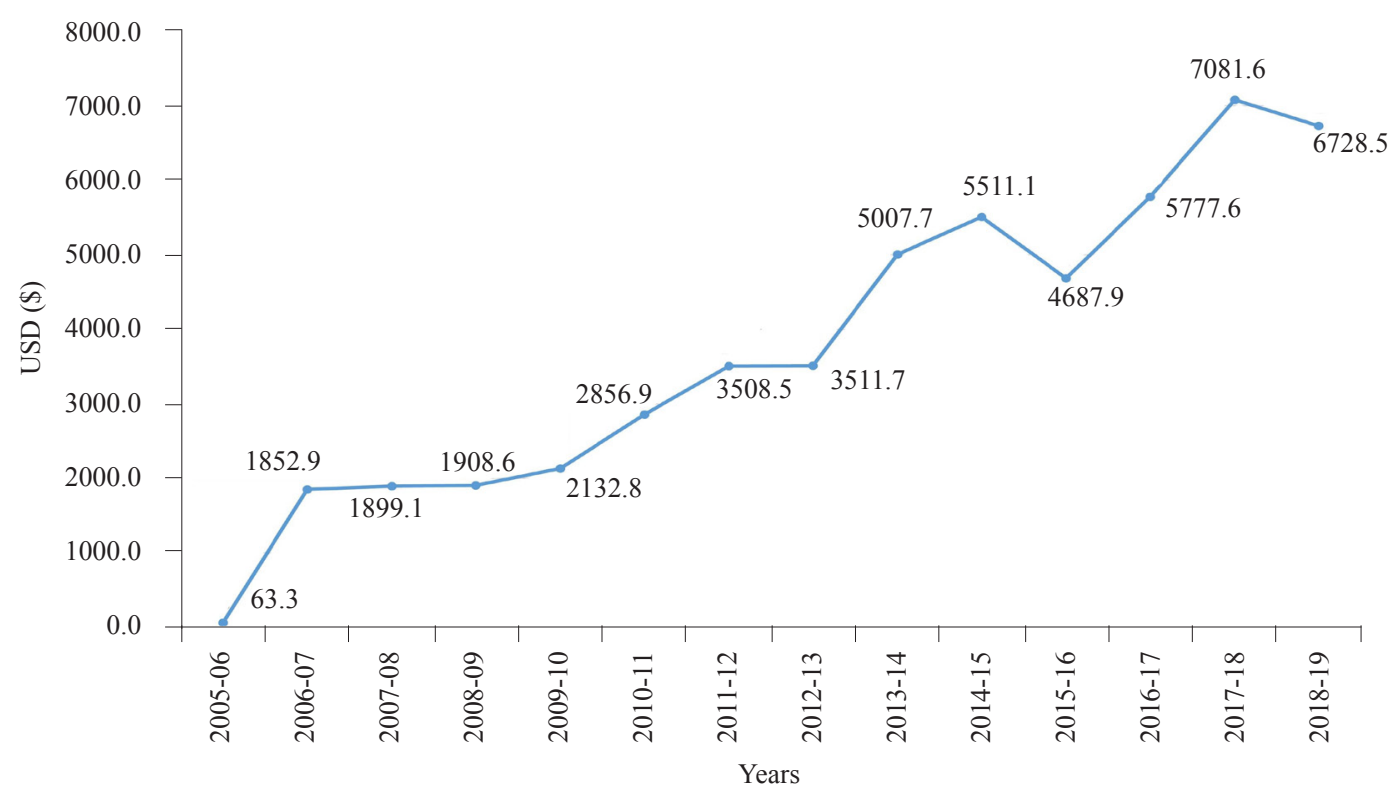

Fig. 6. Trends of marine products exports during 2005-06 to 2018-19 (Source: Ministry of Fisheries, Animal Husbandry and Dairying, Govt. of India) 
form. The ICAR-Central Institute of Fisheries Technology (ICAR-CIFT), Kochi has been playing a pivotal role in modernising the fishing and the fish processing industry in India in the areas of harvest, post-harvest, food safety and quality assurance in fisheries sector. The Institute has been recently notified as a national level referral food laboratory by the Food Safety and Standards Authority of India. There is an increasing need in the country for responsible harvesting of fishery resources based on eco-sustainability and equitable access and utilisation. The harvest sector in fisheries has been enriched by several technological innovations particularly in the marine sector. This includes modernisation of fishing craft and vessels, standardisation of nets and trawlers for deep sea fishing, technologies on sustainable practices, introduction of turtle excluder device (TED) and selective fishing. Similarly, eco-friendly harvest technologies such as optimised gillnets, lines or traps for inland fisheries are other innovations in the sector. The research and developments in the areas of processing, byproducts and packaging of fish or fishery products are progressing in the country. The focus is on complete utilisation of harvested fish through value addition, waste utilisation and appropriate packaging. Several special fishery products viz. fish mince, surimi, balls, cutlets, fingers, patties, burger, coated products and shrimp-based products have been standardised. The value-added fish products include canned products, ready to eat products, extruded products and the recent focus is mostly on restructured products and nutritional protein concentrates. Interestingly, seaweeds have also been used for making cookies, seaweed jelly and yogurts on experimental scale.

Important biomolecules from the processing waste such as chitin, chitosan, fish oil, collagen, gelatin and pigments have been generated converting waste to wealth. In the packaging front, advanced technologies like vacuum packaging, modified atmosphere and active packaging technologies have been developed (Biji et al., 2015). Seafood safety and hygiene assurance have also been addressed by implementing the HACCP (Hazard Analysis Critical Control Point) and EU norms. The technology of DNA barcoding has been introduced to authenticate seafood labelling (Nagalaxmi et al., 2015). However, there are issues and constraints related to raw material, traceability, promotion of domestic marketing and online markets with adequate cold chain facilities.

\section{Climate change and its impact on fisheries}

Climate change and its impact on Indian fisheries and aquaculture has been reviewed comprehensively (Mohanty et al., 2017). Rise in sea surface temperatures (SST), ocean acidification and coral bleaching are increasingly witnessed which are affecting the marine fisheries. Coastal communities and their livelihoods are seriously threatened by cyclones, storms and extreme weather conditions. Changes in oceanic weather systems such as SST, pH, salinity and EL Nino Southern Oscillation (ELSO) are becoming evident as a result of climate change. It is predicted that SST is likely to increase by 2.0 to $3.5^{\circ} \mathrm{C}$ by the end of the century in Indian Ocean. Unnikrishnan et al. (2015) reported that the net sea level has increased by 1.09 to $1.75 \mathrm{~mm}$ year $^{-1}$ in the Indian seas in the last 55 years with faster rise observed along the east coast. Similarly, the number of cyclones occurring in the Bay of Bengal is four times than that in the Arabia Sea (Shaji et al., 2014). Ocean warming and increased stratification of the upper ocean caused by global climate change will lead to decline in the dissolved oxygen with implications on ocean productivity, nutrient cycling, carbon cycling and marine habitat.

Inland fisheries and aquaculture are also severely affected by climate change especially the river systems and their fisheries. The major river systems of India affected by climate change are the Himalayan glacier fed rivers such as Ganga, Brahamaputra and rivers of Deccan plateau including Narmada, Tapti, Godavari and Mahanadi. These rivers will experience more reduced water flow or flooding due to climate change. The changes are likely to affect fish production and biodiversity depending on the severity of the situation.

It is opined that an active partnership between fishermen, managers, scientists and policy planners will provide a better understanding of the climate impacts on fisheries and to evolve adaptation options and mitigation strategies. A mega awareness campaign on the lines of Swachh Bharat Abhiyan is required about the impact, vulnerability, adaptation and mitigation related to climate change among the stakeholders in the fisheries sector. The climate change resilience as an adaptation strategy will help addressing the livelihood security of the stakeholders. It is well established globally that effective fisheries management including the solutions to the problems of over-exploitation, habitat degradation, pollution and climate change could be achieved by adopting an ecosystem based approach. The ecosystem approach will build resilience to the ecological and fisheries effects of climate change.

\section{Capacity building and training of stakeholders}

The major aim for skill development in agriculture and allied sectors is to double the farmers' income by doubling production and reducing input costs. In fisheries sector, Govt. of India has entered into several memoranda of understanding (MOUs) with Government institutes, state agricultural and fisheries universities to take forward the skill development programmes. Shortage of private 
players as training partners necessitates the need to open up the same to Non-Governmental Organisations (NGOs) and corporates having recognised presence in fisheries and aquaculture. It is a challenge to convert the mindset of the institutes and capacity building providers, orienting them to skill-based training programme modules. Presently, majority of them indulge only on knowledge based theoretical learning with minimum focus on applied skills. Most of the institutes lack quality trainers, infrastructure and environment for long-term skill-based training. There is a need to collaborate with industry and private sectors for these purposes including identification of potential partners, training the trainers, master trainers, curriculum and content development, for speeding up the skill development programmes in the fisheries sector and for meeting the increasing skilled manpower requirement in the country.

There are immense entrepreneurship opportunities available in aquaculture. Traditionally, all fisheries capacity building and extension programmes were handled either by State Fisheries Department or through the ICAR Fisheries Institutes and Fisheries Universities and Colleges under State Agricultural Universities. A centrally sponsored scheme on Fisheries Training and Extension provided assistance to various central and state government organisations towards Farmers' Training Centre, publication of handbooks, training manuals, organisation of workshop/symposia/seminar, production of documentary films on fisheries and establishment of awareness centres.

\section{Policies and regulations}

Fisheries and aquaculture development in the country are governed by a number of rules and regulations. The pioneering attempt to regulate fishing in India was the introduction of Indian Fisheries Act 1897 in the British era. The post-independence era witnessed various regulations/legislations/policies, important ones being the Wild Life Protection Act 1972, Forest Conservation Act 1980, Environment Protection Act 1986, Coastal Zone Regulation Notification 1991, Deep Sea Fisheries Policy, 1991, Biological Diversity Act 2002, Comprehensive Marine Fisheries Policy 2004 and Coastal Aquaculture Authority Act 2005. The recent policies on fisheries include the National Policy on Marine Fisheries, 2017 (Box 2), the draft National Mariculture Policy, 2019 (Box 3) and the draft Inland Fisheries and Aquaculture Policy, 2019 (Box 4). The Govt. of India has recently formulated the National Policy for Fisheries 2020 (Box 5), merging the policies on inland fisheries, marine fisheries and the mariculture mentioned above. In addition, a number of state specific policies and notifications have been issued by various state governments for inland and marine sector including marine protected areas (MPAs) from time to time. India is also a signatory for the implementation of several international policy guidelines and agreements including the FAOs Code of Conduct for

\footnotetext{
Box 2: National Policy on Marine Fisheries 2017 (NPMF 2017)

The overarching goal of NPMF 2017 is to ensure the health and ecological integrity of the marine living resources of India's Exclusive Economic Zone (EEZ) through sustainable harvests for the benefit of present and future generations of the nation. The overall strategy of the NPMF 2017 is based on seven pillars namely, sustainable development, socio-economic upliftment of fishers, principle of subsidiarity, partnership and inter-generational equity, gender justice and precautionary approach.

Vision: A healthy and vibrant marine fisheries sector that meets the needs of the present and future generations.

Mission: While keeping sustainability of the resources at the core of all actions, the policy framework will meet the national, social and economic goals, livelihood sustainability and socio-economic upliftment of the fisher community and is intended to guide the coordination and management of marine fisheries in the country during the next ten years.
}

\footnotetext{
Box 3: National Mariculture Policy 2019 (NMP 2019)

A draft National Mariculture Policy (NMP) has been formulated by the Department of Fisheries, Govt. of India. The goal of the NMP is to ensure sustainable farmed seafood production for the benefit of food and nutritional security of the nation and to provide additional livelihood and entrepreneurial opportunities for the coastal communities for better living. The overall strategy of the policy is to increase seafood production in sustainable and responsible manner, ensure socio-economic development, enhance food, health and nutritional security and safeguard gender, social equity and environment.

Vision: A sustainable and responsible mariculture sector that contributes to the food and nutritional security of the country and enhances the quality of life of the stakeholders.

Mission : A policy framework leading to widespread adoption of mariculture technologies to meet the additional seafood demand while ensuring environmental sustainablility, socio-economic upliftment of stakeholders and facilitating responsible development, co-ordination and management of mariculture production in the country.
} 


\begin{abstract}
Box 4: National Inland Fisheries and Aquaculture Policy 2019 (NIFAP 2019)
A draft National Inland Fisheries and Aquaculture Policy (NIFAP) has been formulated by the Department of Fisheries, Govt. of India. The overall objective of NAIFAP is to create an enabling environment for the sustainable development of inland fisheries and aquaculture in the country, to ensure food and nutritional security, gainful employment and livelihoods, economic prosperity and ecological health. The scope of NIFAP encompasses development and management of all inland fishery resources including aquaculture in freshwater, brackishwater and landlocked saline/alkaline areas. The NIFAP adopts an Ecosystem Approach to Fisheries (EAF) management within the overall framework of relevant national and international instruments and policies.

Vision: Ecologically healthy, economically viable and socially inclusive inland fisheries and aquaculture that generates gainful employment and economic prosperity.

Mission: To develop, manage, conserve and sustainably utilise the inland fisheries and aquaculture resources of the country for improving livelihood; generating gainful employment; ensuring food and nutritional security, economic prosperity and wellbeing through appropriate strategies and legislations, stakeholders' participation, public-private and community partnership, market support and by strengthening research, extension and their linkages.
\end{abstract}

\footnotetext{
Box 5: National Fisheries Policy 2020 (NFP 2020)

A National Fisheries Policy 2020 has been formulated by the Ministry of Fisheries, Animal Husbandry and Dairying, Govt. of India with an objective to develop, harness, manage and regulate capture and culture fisheries in a responsible and sustainable manner based on cardinal principles of equity and equality and adopting a people centric and participatory approach.

Vision: To develop an ecologically healthy, economically viable and socially inclusive fisheries sector that contributes towards economic prosperity and wellbeing of fishers and fish farmers and provides food and nutritional security to the country in a sustainable and responsible manner.

Mission: To develop and manage fisheries resources of the country and to harness, utilise, regulate and conserve the resources responsibly for improving livelihoods, generating gainful employment, enhancing incomes, food and nutrition security, economic prosperity and socio-economic wellbeing of stakeholders, especially artisanal and small-scale fishers and fish farmers through appropriate strategies and partnership in a participatory manner.
}

Responsible Fisheries, Ecosystem Approach to Fisheries Management and the Convention on Biological diversity (CBD).

As per the Seventh Schedule of the Indian Constitution, the states have the jurisdiction to govern fishing and fisheries in the territorial waters up to 12 nautical miles from the base line, whereas the Union Govt. has jurisdiction beyond territorial waters i.e. between 12 nautical miles and 200 nautical miles. The marine fisheries activities within the territorial waters of a maritime state are governed by the respective Marine Fisheries Regulatory Acts (MFRAs). The MFRAs contain several provisions to regulate, restrict as well as prohibit unsustainable and destructive fishing practices to define access rights, to impose spatial and temporal fishing restrictions and to make licensing and registration of fishing vessels compulsory.

Govt. of India has fixed the ban period on fishing for 61 days (April 15 - June 14 in the east coast and June 1 - July 31 in the West coast). One important regulation under MFRAs in recent years is of size regulation of fish caught in the state, wherein Govt. of Kerala has notified minimum length size of 50 species of fish and shellfish in 2015. It is expected that the regulation on gear size will play a pivotal role in preventing juvenile fishing which is rampant all along the coast. In conclusion, it shows that there are enough regulations and acts in the country to safeguard the fishermen as well as fisheries by ensuring sustainability of the resources. What remains to be done is the effective implementation of regulations by the concerned agencies. The central and state machinery needs to work in harmony for the sustainability of the resources ensuring food and nutritional security to the burgeoning population.

\section{Challenges in the growth of fisheries and aquaculture}

The fisheries and aquaculture have witnessed impressive growth in recent years. The sector is growing at an average growth rate of $5.86 \%$, with the marine and inland sectors growing at 2.42 and $9.01 \%$ respectively during 2007-08 to 2017-18 (Fig. 7). The two major constraints impacting the marine resources and fisheries are poor governance and overexploitation due to overcapacity. The overexploitation has been recognised as one of the key threats to global biodiversity (Trindade-Santos et al., 2020). Other important factors include vagaries of climate change, traditional fishing and harvesting practices, poor infrastructure especially of fishing harbours and landing centres, lack of sufficient cold chain and processing facilities for value addition, post-harvest losses and shortage of skilled manpower 


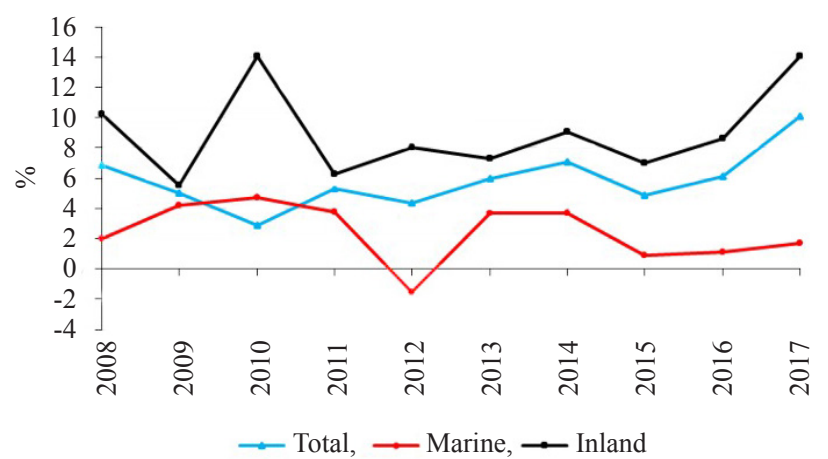

Fig. 7. Growth rate of Indian fisheries during 2007-08 to 2017-18

(Fig. 8). The aquaculture sector despite its fast growth, is facing the challenges of quality seed, feed, disease and improved breed. Diversification of fish species has provided some options but mass scale seed production of several of these new candidates still remains elusive. The use of genetically improved seed of Jayanti rohu in the freshwater aquaculture is providing rich dividends, but no such choices are available in the brackishwater and mariculture sectors for improved indigenous species. A largely, low input culture practice with low productivity reflects low adoption of modern technology and scientific farming in the inland aquaculture. Lack of skills and institutional credit in aquaculture including both freshwater and marine are other impediments to faster growth and enhanced production. The aquaculture sector

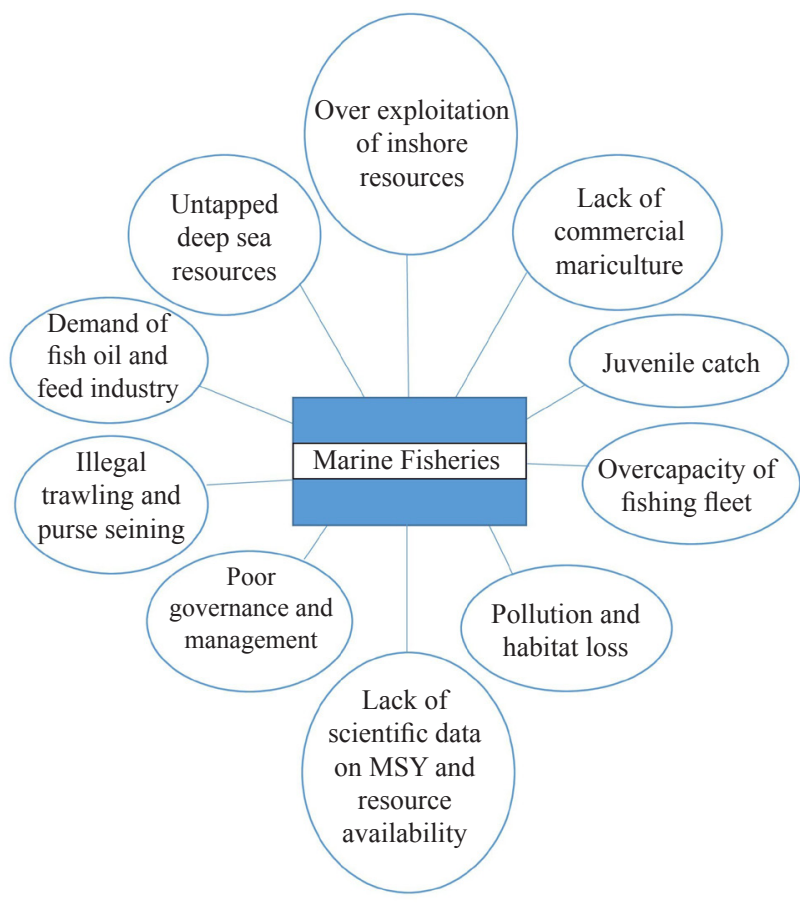

Fig. 8. Factors responsible for stagnating marine fisheries is also confronted with reduced availability of water in the inland areas, disease outbreaks in fish and shrimp farming, cumbersome institutional credit and increasing input costs especially of feed. Therefore, addressing all these issues through research and development as well as policy formulation is of utmost importance for realising the goals of blue revolution under a mission mode approach.

\section{Future perspectives and recommendations}

The main objective of the new schemes namely, PMMSY, Fisheries and Aquaculture Infrastructure Development Fund (FIFA) and Blue Revolution launched in the country is to enhance production and productivity along with modern infrastructure development, increased employment generation for youth and women, improved socio-economic conditions of fisherfolks, augmentations of exports and adopting an integrated approach to marine and inland fisheries towards responsible and sustainable fisheries and aquaculture development. It is directed at comprehensive development of the sector through innovative technology applications and policy interventions addressing the critical gaps in knowledge, technology and governance.

The marine capture fisheries is plagued with declining catches due to excess capacity of fishing fleets, juvenile catch besides aquatic pollution and climate variability. An ecosystem approach to fisheries management and the state and region specific management plans are advocated to be effectively implemented by central and state governments towards providing solutions to the depleting resources and alternate livelihood options for the coastal communities. The exploitation of deep sea resources and the increased application of remote sensing and space technology in locating new fishing grounds holds a great promise. The recent initiatives of the Govt. of India namely Sagarmala and PMMSY are mainly directed towards enhancing the production and productivity, strengthening the value chain including infrastructure, post-harvest management, quality control and marketing.

There is immense scope in aquaculture sector through both horizontal expansions and vertical intensive farming using advanced technologies of recirculating aquaculture systems (RAS) and integrated multi-trophic aquaculture (IMTA). Hi-tech aquaculture may enhance vulnerability to diseases but a coordinated approach between the central and state agencies will help to timely mitigate and control diseases in aquaculture. A national program on aquatic animal disease surveillance involving more than 20 national organisations, 16 states and 3 Union Territories is already underway under its second phase. A fisheries agency at central and state level is proposed to be created to address standards and diseases in aquaculture. 
Cage culture in sea and reservoirs, integrated fish farming, ornamental fish culture and seaweed farming are the sectors of immense potential which have been prioritised to be upscaled and promoted with appropriate technology and diversification of species and associated support for large scale expansion creating new employment and alternate livelihood options to fishers and fish farmers.

Domestic fish marketing infrastructure has been upgraded in selected pockets in the country in recent years. However, development of new domestic markets across the country with adequate levels of hygiene remains elusive and it needs to be addressed on priority. Similarly, India is one of the leading countries in seafood export and strengthening and modernising the value-chain to increase shelf life, reduction in post-harvest losses and production of more value added products for the domestic and international markets are on the priority agenda under the New India Vision. Efforts are being made on value addition of export items so as to bring higher acceptability, value per unit and meeting the target of foreign exchange to the tune of ₹1,00,000 crores (USD 1000 billion) by 2025 as envisioned by the Government.

The goals of sustainable fisheries and aquaculture development in India are targeted to be achieved through appropriate fisheries policy framework, improved management and governance and strong partnership amongst the stakeholders. The environmental, economic and social sustainability of aquaculture systems have to be addressed based on quantitative indicators (Valenti et al., 2018). A sectoral mission mode approach is suggested for realising the full potential of the sector towards blue revolution encompassing the principles of blue economy and blue growth initiative.

The following specific recommendations are provided to further transform the fishery sector of India:

- The economic, environmental and biological sustainability of aquatic resources is critical to fisheries management. Therefore, the National Fisheries Policy (NFP) should be strongly aligned with sustainability of resources and livelihoods of the traditional fishing communities. The fishing communities should be involved in responsible actions in the resource conservation, rather than simply invovlving beneficiaries of the state and central government schemes.

- Special emphasis is required to be given to increase the domestic consumption of fish and shrimps through innovative marketing strategies based on the success stories of poultry and dairy sector. This will address the marketing issue of shrimps during pandemics wherein international exports are badly affected for months together affecting the whole industry, there by incurring great losses.
- The umbrella scheme of blue revolution and PMMSY should have a major focus on blue economy encompassing target oriented programmes on deep sea fishing, marine aquaculture and biotechnology. The capacity development in the exploitation of the deep sea resources, open sea cage farming including seaweed farming and marine ornamental fish culture should be taken up with quantitative targets. The captive breeding and mass scale seed production of potential marine cultivable fish species along with feed mills are required to be undertaken all along the Indian coast. Marine biotechnology has immense potential for cutting edge research in bioprospecting and green growth.

- A strategy of on the job mentoring of farmers and fishers by scientists/experts on regular basis at their fields has proved very effective in several countries including China. A country with third largest scientific manpower in the world, should therefore consider this and mandate the research and development organisations to develop action plans for farmer mentors in the aquaculture sector.

- A National Academy of Fisheries and Aquaculture (NAFA) should be established as a platform for policy advocacy and support to the farmers and to strengthen national and international interface and collaborations.

- $\quad$ The role of coastal and marine fishers in the fisheries sector is well recognised for their significant contribution to food security. Representation of these communities and their wards in the fisheries higher education is almost negligible. A special scheme needs to be formulated on the lines of the civil service coaching to Scheduled Caste/Scheduled Tribe communities in the country, with an objective to facilitate a minimum representation in degree courses for the wards of fishing communities in all fisheries colleges.

- $\quad$ The coastal security and safety at sea has assumed global significance in view of increased threats from pirates and terrorists. Youth from coastal villages should be motivated and prepared for national services especially by special recruitment drives in navy, coast guard, coastal police and forest services.

- A global partnership in fisheries research and development is the need of the hour. The recent National Education Policy and the administrative reforms implemented in the federal ministries and structures brings several opportunities for the scientific and academic community to develop partnership with reputed organisations in terms of joint degree programmes, exchange of faculty and students and sharing of advanced knowledge.

- Diversification in aquaculture through the establishment of regional hatcheries of new candidate species whose seed production technology has been standardised. This needs to be accomplished with funding from Blue Revolution/ PMMSY schemes which will facilitate mass seed production and its availability to the farmers on a sustainable basis for both freshwater and marine aquaculture.

- $\quad$ Formation of fish farmer producer organisations (FPOs) holds great promise. The schemes of NABARD and 
Govt. of India provide several opportunities for these beneficiaries covering the complete value chain from production to market.

- A comprehensive third party review of the central scheme on Blue Revolution implemented through the state/union territories covering all the states and beneficiaries for its impact on the sector is required in terms of success stories, challenges and lessons learnt. This will provide new insights for effective implementation of PMMSY towards improved management of the fisheries sector.

\section{Acknowledgements}

The first author is grateful to National Bank for Agriculture and Rural Development (NABARD) for the financial support.

\section{References}

Ayyappan, S. 2012. Indian fisheries: Issues and the way forward. National Academy of Science Letters, 35: 1-6.

Ayyappan, S., Jena, J. K., Gopalakrishnan, A. and Pandey, A. K. 2013. Handbook of fisheries and aquaculture. Directorate of Knowledge Management in Agriculture, Indian Council of Agricultural Research, New Delhi, India, 1116 pp.

Belton, B., Padiyar, A., Ravibabu, G. and Rao, K. G. 2017. Boom and bust in Andhra Pradesh: Development and transformation in India's domestic aquaculture value chain. Aquaculture, 470: 196-206. DOI : 10.1016/j.aquaculture. 2016.12.019.

Biji, K. B., Ravishankar, C. N., Mohan, C. O. and Srinivasa Gopal, T. K. 2015. Smart packaging systems for food applications: A review. Food Sci. Technol., 52(10): 6125-6135. doi: 10.1007/s13197-015-1766-7.

Christopher, B., Barange, M., Subasinghe, R., Per-PinstrupAndersen, G., Merino Gro-Ingunn H. and Williams, M. 2015. Feeding a billion by 2050 - Putting fish back on the menu. Food Security, 7: 261-274.

CMFRI 2020. Marine fish landings in India 2019, Technical Report. CMFRI Booklet Series No. 24/2020. ICAR-Central Marine Fisheries Research Institute, Kochi, India, 15 pp.

Debajit Sarma, M. S. Akhtar, N. N. Pandey, Neetu Shahi, B. P. Mohanty and Mahanta, P. C. 2011. Nutrient profile and health benefits of coldwater fishes, Bulletin No. 17. ICARDirectorate of Coldwater Fisheries Research, Bhimtal, Uttarakhand, India, $40 \mathrm{pp}$.

Edwards, P., Zang, W., Belton, B. and Little, D. C. 2019. Misunderstandings, myths and mantra in aquaculture: Its contribution to world food supplies has been systematically over reported. Mar. Policy, 106: 103547. DOI: 10.1016/j. marpol.2019.103547.

Felix, S., Anna Mercy, T. V. and Swain, S. K. 2013. Ornamental aquaculture and trade in India. Daya Publishing House, New Delhi, India.
FAO 2020. The state of world fisheries and aquaculture. Food and Agriculture Organisation of the United Nations, Rome, Italy, $244 \mathrm{pp}$.

GoI 2018. Handbook on fisheries statistics 2018. Department of Animal husbandry, Dairying and Fisheries, Ministry of Agriculture, Government of India, Krishi Bhavan, New Delhi.

GoI 2020a. National fisheries policy, 2020. Department of Fisheries, Ministry of Fisheries, Animal Husbandry and Dairying, Govt. of India, 32 pp. https://nfdb.gov.in/PDF/ National_Fisheries_Policy_2020.pdf.

GoI 2020b. PIB release on New Schemes for Fisheries. Ministry of Fisheries, Animal Husbandry and Dairying, Govt. of India, New Delhi, India.

Jayasankar, P. 2018. Present status of freshwater aquaculture in India-A review. Indian J. Fish., 65(4): 157-165. DOI: 10.21077/ijf.2018.65.4.81300-20.

Katiha, P. K., Jena, J. K., Pillai, N. G. K., Chakraborty, C. and Dey, M. M. 2005. Inland aquaculture in India: Past trend, present status and future prospects. Aquac. Econ. Manage., 9: 237-264. DOI: 10.1080/13657300590961573.

Kaladharan, P., Johnson, B., Nazar, A. K., Boby Ignatius, Kajal Chakraborty and Gopalakrishnan, A. 2019. Perspective plan of ICAR-CMFRI for promoting seaweed mariculture in India. Mar. Fish. Inf. Serv. T\&E Ser., 240: 17-22.

Lakra, W. S., Reddy, A. K. and Harikrishna, V. 2014. Technology of commercial farming of Pacific white shrimp, Litopenaues vannamei in inland saline soils using ground saline water. ICAR-Central Institute of Fisheries Education, Technical Bulletin No. 1, 28 pp.

Lal, K. K. and Jena, J. K. 2019. Fish genetic resources - India. In: Rishi K. Tyagi, Munasinghe, D. H. N., Ashoka Deepananda, K. H. M., Frank Niranjan and Ravi K. Khetarpal (Eds.), Regional Workshop on Underutilized fish and marine genetic resources and their amelioration - Proceedings and recommendations. 10-12 July 2019, Asia-Pacific Association of Agricultural Research Institutions (APAARI), Bangkok, Thailand, $55 \mathrm{pp}$.

Mohanty, B., Vivekanandan, E., Mohanty, S., Trivedi, M., Tripathy, S. and Sahu, J. N. 2017. The impact of climate change on marine and Inland fisheries and aquaculture in India. In: Bruce F. Philips and Monica Perez-Ramirez (Eds.), Climate change impacts on fisheries and aquaculture: A global analysis, vol. 2. Wiley-Blackwell. New Jersey, USA, p. 569-602.

Munilkumar, S. and Nandeesha, M. C. 2007. Aquaculture practices in Northeast India: Current status and future directions. Fish Physiol. Biochem., 33(4): 399-412. DOI: 10.1007/s10695-007-9163-4.

Nagalaxmi, K., Annap, P., Venkatshwarlu, G., Pathakota, G. B. and Lakra, W. S. 2015. Mislabelling in Indian seafood: An investigation using DNA barcoding. Food Control, 59: 196-200. DOI:10.1016/j.foodcont.2015.05.018. 
Nair, L. 2014. Emerging trends in Indian aquaculture. J. Aquat. Biol. Fish., 2(1): 1-5.

New, M. B., Valenti, W. C., Jidwal, J. H., D’Abramo, L. R. and Kutty, M. N. 2010. Freshwater prawns: Biology and farming. Wiley-Blackwell, New Jersey, USA, 531 pp.

NFDB 2019. Aquaculture technologies implemented by NFDB. National Fisheries Development Board, Department of Fisheries Ministry of Fisheries, Animal Husbandry and Dairying, Govt. of India, Hyderabad, India, 58 pp.

Ranjan, R., Megaranjan, S., Xavier, B., Ghosh, S., Santosh, B. and Gopalakrishnan, A. 2018. Broodstock development, Induced breeding and larval rearing of Indian pompano, Trichinotus mookalee (Civier 1832) - A new candidate species for aquaculture. Aquaculture, 495: 265-272.

Syda Rao, G., Imelda Joseph, Philopose, K. K. and Suresh Kumar, M. 2014. Cage culture in India. Aquac. Int., 22: 961-962.

Shaji, C., Sajal, K. K. and Vishal, T. 2014. Storm surge studies in the North Indian Ocean: A review. Indian J. Geo-Mar. Sci., 43(2): 125-147.

Sinha, V. R. P., Gupta, M. V., Banerjee, M. K. and Kumar, D. 1973. Composite fish culture in Kalyani. J. Inland Fish. Soc. India. 5: 201-208.

Shinoj, P., Gopalakrishnan, A. and Jena, J. K. 2020. Demographic change in marine fishing communities in India.
In: Demographic change in Asian fishing communities: Drivers, outcomes and potential impacts. Food and Agriculture Organisation of the United Nations, Rome, Italy, p 85-102.

Taryn, G., Frank, A., James, A., Bjorndal, T., Kumar, G., Lorenzen, K., Ropick, A., Smith, M. D. and Tveteras, R. 2020. A global blue revolution: Aquaculture growth across regions, species and countries. Rev. Fish. Sci. Aquac., 28: 107-116. https://doi.org/10.1080/23308249.2 019.1678111 .

Trindade-Santos, I., Moyes, F. and Magurran, A. E. 2020. Global change in the functional diversity of marine fisheries exploitation over the past 65 years. Proc. R. Soc. Biol. Sci. Ser. B., 287: 2020 0889. DOI: 10.1098/rspb.2020.0889.

Unnikrishnan, A. S.. Manimurali, M. and Ramesh Kumar, M. R. Sea-level changes along the Indian coast. Inputs to Indian Network for Climate Change Assessment, National Institute of Oceanography, Goa, India.

Valenti, W. C., Kimpara, J. M., Preto, B. D. L. and MoraesValenti, P. 2018. Indicators of sustainability to assess aquaculture systems. Ecol. Indic., 88: 402-413. https://doi. org/10.1016/j.ecolind.2017.12.068.

Vijayan, K. K. 2019. Domestication and genetic improvement of Indian white shrimp, Penaeus indicus: A complimentary native option to exotic pacific white shrimp, Penaeus vannamei.J. Coast. Res., 86(spl.): 270-276. 